Pemanfaatan Jurnal Online Perpustakaan BPTP Yogyakarta Dwi Titaningsih, Suharno

Kerja Sama antara SDM Perpustakaan untuk Menuju Layanan Prima dan Unggul Endang Fatmawati

Revitalisasi Peran Perpustakaan Umum bagi Masyarakat Noorika Retno Widuri

Optimalisasi Layanan Penelusuran Sumber-sumber Informasi untuk Mendukung Penulisan Karya Ilmiah Dosen dan Mahasiswa di Perguruan Tinggi Dian Hapsari

Memperkuat Peran Pustakawan dalam Mewujudkan Layanan Perpustakaan Perguruan Tinggi yang Prima dan Unggul Bambang Hermanto

Aktivitas Mahasiswa dalam Membaca Skripsi di Perpustakaan Masriyatun

Budaya Peduli dan Budaya Mutu Melayani di Perpustakaan SMP Negeri 13 Surakarta Menuju Sekolah Menyenangkan Ria Widyawati

Redesain Website UPT Perpustakaan Universitas Sebelas Maret sebagai Media Pendidikan Pengguna bagi Pemustaka Tri Hardian Satiawardana

Peran Perpustakaan dalam Membangun Citra Perpustakaan di Era Teknologi Informasi Sri Anawati

Komunitas Pustakawan Menulis (upaya menyebarluaskan dan melestarikan pengetahuan) Tri Hardiningtyas 


\section{Jurnal}

\section{Pustaka Ilmiah}

\section{Jurnal Ilmiah UPT Perpustakaan UNS}

Jurnal Pustaka Ilmiah (JPI) sebagai media kreasi para pustakawan, guru, dosen, dan praktisi dalam pengembangan profesi secara berkelanjutan. Berbagai ide dan gagasan kreatif menjadi bahan kajian yang diimplementasikan dalam berbagai model pengembangan bahan pustaka, baik cetak maupun online. Kreativitas menjadi akar pengembangan ilmu pengetahuan sepanjang hayat dengan berbagai model pengembangan budaya literasi di perpustakaan. Keindahan dan kecermatan dalam sebuah tulisan ilmiah dan nonilmiah akan dapat direalisasikan secara nyata oleh sumber daya manusia untuk menghasilkan SDM yang unggul dan kreatif dengan membaca dan menulis untuk menyinari dunia. Budaya literasi menjadi upaya untuk pengembangan dan pemberdayaan perpustakaan sebagai pusat sumber belajar untuk mendukung tri dharma perguruan tinggi.

\section{SUSUNAN REDAKSI}

Penanggung Jawab

Ketua Redaksi

Wakil Redaksi

Sekretaris

Penyunting Ahli

Penyunting

Bendahara

Sirkulasi
: Dr. Muhammad Rohmadi, M.Hum.

: Dra. Tri Hardiningtyas, M.Si.

: Haryanto, M.IP.

: Bambang Hermanto, S.Pd., M.IP., Henny Perwitosari, A.Md.

: 1. Dr. Muhammad Rohmadi, M.Hum. (Universitas Sebelas Maret);

2. Drs. Widodo, M.Soc.Sc. (Universitas Sebelas Maret);

3. Drs. Harmawan, M.Lib. (Universitas Sebelas Maret).

: Daryono, S.Sos., M.IP.; RiahWiratningsih, S.S., M.Si., Dinar Puspita Dewi, S.Sos., M.IP.; Sri Utari, S.E.

: Nurul H., A. Md.; Novi Tri Astuti, A.Md.

: Aji Hartono, A. Md.; Agus Sriyono, A.Md.; Aris Suprihadi, S.IP.

UPT PERPUSTAKAAN UNS

REDAKSI JURNAL PUSTAKA ILMIAH

Alamat: Jl. Ir. Sutami 36A Kentingan, Surakarta 57126

Telp./Fax.: (0271) 654311; email: jurnal.pustaka.ilmiah@gmail.com 


\section{Pengantar Redaksi}

\section{Salam Pustaka.}

Dengan mengucap rasa syukur kepada Allah SWT. segenap Tim Redaksi Jurnal Pustaka Ilmiah (JPI) mengucapkan banyak terima kasih kepada para penulis yang telah berkontribusi untuk penerbitan JPI volume 2 edisi Juni 2016. Penerbitan volume 2 kali ini JPI mengetengahkan tema: Pengembangan Perpustakaan menuju Layanan Prima dan Unggul. Kehadiran JPI diharapkan dapat dijadikan sebagai media penulisan bagi para pustakawan, dosen, tenaga kependidikan, guru, dan praktisi untuk menuangkan ide dan gagasan kreatifnya secara tertulis.

Dalam penerbitan JPI volume 2 bulan Juni 2016 ini disajikan sepuluh tulisan antara lain: (1) Pemanfaatan Jurnal Online Perpustakaan BPTP Yogyakarta (Dwi Titaningsih dan Suharno), (2) Kerja Sama Antara Sumber Daya Manusia Perpustakaan untuk Menuju Layanan Prima dan Unggul (Endang Fatmawati), (3) Revitalisasi Peran Perpustakaan Umum Bagi Masyarakat (Noorika Retno Widuri), (4) Optimalisasi Layanan Penelusuran Sumber-Sumber Informasi untuk Mendukung Penulisan Karya Ilmiah Dosen dan Mahasiswa di Perguruan Tinggi (Dian Hapsari), (5) Memperkuat Peran Pustakawan dalam Mewujudkan Layanan Perpustakaan Perguruan Tinggi yang Prima dan Unggul (Bambang Hemanto), (6) Aktivitas Mahasiswa dalam Membaca Skripsi di Perpustakaan FISIP-UNS (Masriyatun), (7) Budaya Peduli dan Budaya Mutu Melayani di Perpustakaan SMP Negeri 13 Surakarta Menuju Sekolah Menyenangkan (Ria Widyawati), (8) Redesain Website UPT Perpustakaan Universitas Sebelas Maret Surakarta sebagai Media Pendidikan Pengguna Bagi Pemustaka (Tri Hardian Satiawardana), (9) Peran Perpustakaan dalam Membangun Citra Perpustakaan di Era Teknologi Informasi (Sri Anawati), (10) Komunitas Pustakawan Menulis : upaya menyebarluaskan dan melestarikan pengetahuan (Tri Hardiningtyas).

Akhirnya, redaksi JPI mengucapkan banyak terima kasih kepada Kepala UPT Perpustakaan UNS yang telah memberikan dukungan dan memfasilitasi untuk penerbitan JPI. Selain itu, ucapan terima kasih juga disampaikan kepada para penulis, tim redaksi, dan Yuma Pressindo, yang telah mempersiapkan dari awal sampai terbitnya JPI. Selamat membaca.

Surakarta, Juni 2016

Ketua Redaksi 


\section{Sambutan}

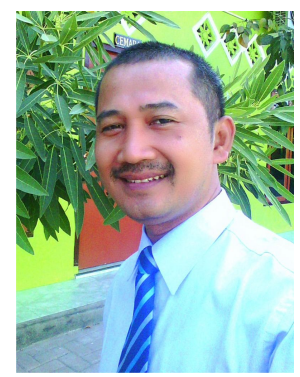

Dr. Muhammad Rohmadi, M.Hum.

\section{Kepala UPT Perpustakaan UNS}

Selamat dan sukses atas diterbitkannya kembali Jurnal Pustaka Ilmiah (JPI). Jurnal ini sebagai media kreativitas dan pengembangan softs skills para pustakawan, guru, dosen, dan praktisi untuk menuangkan ide dan gagasan demi layanan perpustakaan yang prima dan unggul. Berbagai isu terkait dengan pengembangan perpustakaan, pelayanan perpustakaan sebagai pusat sumber belajar, pendidikan, penelitian, pelestarian, dan budaya literasi akan menjadi topik-topik yang disajikan dalam jurnal ilmiah ini.

Diterbitkannya JPI sebagai bukti kepedulian UPT Perpustakaan Universitas Sebelas Maret Surakarta (UNS) dalam rangka turut berpartisipasi mengembangkan dan membudayakan literasi untuk para pustakawan dan civitas akademika di UNS maupun luar UNS. Berbagai model pengembangan softs skills menjadi alternatif untuk membekali dan memperkuat jaringan kerja sama penulisan antar kelembagaan. Dengan demikian, kerja sama antar pustakawan dan pemustaka dapat diwujudkan dengan berbagai model dalam bidang literasi.

Penerbitan JPI merupakan sarana untuk memotivasi semua pustakawan agar berkarya di bidang penulisan, baik ilmiah maupun nonilmiah. Para pustakawan harus menjadi pionir dalam bidang penulisan. Hal ini sebagai bentuk kepedulian dan keteladaan para pustakawan yang memproses, menyajikan, dan menikmati bahan-bahan pustaka cetak dan noncetak di perpustakaan. Ketersedian bahan pustaka akan menjadi bahan paling nyata untuk dikembangkan dalam berbagai model perwujudan teknik penulisan. Hal terpenting yang harus dimiliki oleh para pustakawan adalah semangat untuk berbagi pengetahuan melalui tulisan.

Kepedulian setiap sumber daya manusia kepada kelembagaan dapat dituangkan dalam berbagai model pengabdian, salah satunya adalah melalui tulisan. Berbagai ide dan gagasan dapat direalisasikan dengan berbagai model bentuk artikel jurnal, buku, modul, monograf, dan lain sebagainya. Para civitas akademika, guru, praktisi harus memiliki keterampilan menulis sebagai bentuk perwujudan pengembangan diri secara berkelanjutan. Berbagai tulisan dan referensi sudah disajikan tetapi masih sangat minim untuk diimplementasikan dalam kehidupan. Banyak orang pandai dalam berbicara tetapi masih sedikit yang menuangkan ide dan gagasannya dalam bentuk tulisan.

Akhirnya, keluarga besar UPT Perpustakaan UNS mengucapkan banyak terima kasih kepada Rektor, Wakil Rektor, pengelola JPI, penulis, dan semua pihak yang telah mendukung penerbitan JPI. Semoga dengan diterbitkannya JPI ini dapat menjadi media untuk menulis para pustakawan, dosen, guru, dan praktisi dalam bidang iptek dan seni. Ucapan terima kasih juga diucapkan kepada percetakan Yuma Pressindo yang telah membantu mempersiapkan dari awal sampai terbitnya JPI ini. Akhirnya, semoga JPI dapat memberikan nilai kemaslahatan untuk umat. 


\section{DAFTAR ISI}

\section{JURNAL PUSTAKA ILMIAH EDISI KEDUA: VOLUME 1 NOMOR 2/ JUNI 2016}

\section{Tema: Pengembangan Perpustakaan Menuju Layanan Prima dan Unggul}

Pemanfaatan Jurnal Online Perpustakaan BPTP Yogyakarta

Dwi Titaningsih, Suharno

Kerja Sama antara SDM Perpustakaan untuk Menuju Layanan Prima dan Unggul

Endang Fatmawati

Revitalisasi Peran Perpustakaan Umum bagi Masyarakat.

Noorika Retno Widuri

Optimalisasi Layanan Penelusuran Sumber-sumber Informasi untuk Mendukung Penulisan Karya Ilmiah Dosen dan Mahasiswa di Perguruan Tinggi..

Dian Hapsari

Memperkuat Peran Pustakawan dalam Mewujudkan Layanan Perpustakaan Perguruan Tinggi yang Prima dan Unggul.

Bambang Hermanto

Aktivitas Mahasiswa dalam Membaca Skripsi di Perpustakaan

Masriyatun

Budaya Peduli dan Budaya Mutu Melayani di Perpustakaan SMP Negeri 13 SurakartaMenuju SekolahMenyenangkan.

Ria Widyawati

Redesain Website UPT Perpustakaan Universitas Sebelas Maret sebagai Media Pendidikan Pengguna bagi Pemustaka.

Tri Hardian Satiawardana

Peran Perpustakaan dalam Membangun Citra Perpustakaan di Era Teknologi Informasi

Sri Anawati

Komunitas Pustakawan Menulis (upaya menyebarluaskan dan melestarikan pengetahuan)

Tri Hardiningtyas 


\title{
KERJA SAMA DI ANTARA SDM PERPUSTAKAAN UNTUK MENUJU LAYANAN PRIMA DAN UNGGUL
}

\author{
Endang Fatmawati \\ Kepala Perpustakaan FEB UNDIP
}

\begin{abstract}
Internal problems among the human resources in each library must exist. To achieve service excellence and superior library requires cooperation. Cooperation among individuals there is a need of every library. Solid team work is the key to success in managing the library. The practice of cooperation among individuals in the library can be assessed based on aspects of social relations and the exchange of knowledge.
\end{abstract}

Keywords: team work, cooperation, human resources, library

\begin{abstract}
ABSTRAK
Permasalahan internal di antara sumber daya manusia di setiap perpustakaan pasti ada. Untuk mencapai layanan perpustakaan yang prima dan unggul membutuhkan kerja sama. Kerja sama antarindividu yang ada merupakan kebutuhan setiap perpustakaan. Tim kerja yang solid menjadi kunci keberhasilan dalam mengelola perpustakaan. Praktik kerja sama antarindividu di perpustakaan dapat dikaji berdasarkan aspek relasi sosial dan pertukaran pengetahuan.
\end{abstract}

Kata kunci: tim kerja, kerja sama, sumber daya manusia, perpustakaan

\section{PENDAHULUAN}

Dalam setiap perpustakaan, yang namanya permasalahan internal pasti ada. Beberapa permasalahan yang sering muncul di antara SDM yang ada di perpustakaan tersebut, misalnya: kesenjangan antara pimpinan dan bawahan, perbedaan pegawai senior dan junior, resistensi, perbedaan nilai dan keyakinan, kurang komunikasi, sampai dengan tidak adanya kerja sama di antara mereka.

Dinamika perubahan gaya hidup yang semakin mengglobal dan perkembangan teknologi yang semakin canggih mengakibatkan praktik kerja sama menjadi semakin kompleks. Dilihat dari tinjauan budaya, kerja sama antarSDM dalam suatu perpustakaan merupakan realitas sosial yang perlu dikaji lebih dalam. Idealnya, untuk mencapai layanan perpustakaan yang prima dan unggul, dibutuhkan kerja sama tim kerja yang solid. Bagaimana pun faktor SDM di perpustakaan merupakan suatu keharusan (conditio sine quanon) tidak dapat diabaikan.

Permasalahan yang penulis angkat dalam tulisan ini adalah tentang kerja sama antar-SDM yang ada di perpustakaan untuk menciptakan layanan prima dan unggul. Tujuannya adalah menjelaskan pentingnya aspek kerja sama antar-SDM di perpustakaan. Kajian yang akan dikupas dalam pembahasan mencakup: konsep kerja sama, relasi sosial, dan pertukaran pengetahuan. 


\section{PEMBAHASAN}

\section{Konsep Kerja Sama}

Kerja sama bahasa Inggrisnya cooperation. Asal katanya co, artinya bersama-sama dan operation, yang artinya bekerja. Secara umum, kerja sama merupakan kegiatan yang dilakukan oleh masing-masing SDM di perpustakaan untuk mencapai tujuan bersama. Dalam Laksmi (2015: 35), dijelaskan kalau praktik kerja sama antarindividu dapat diamati dari dua aspek, yaitu berdasarkan aspek relasi sosial dan pertukaran pengetahuan.

Terkait dengan SDM, Lasa (2005: 62) menyampaikan bahwa SDM merupakan faktor yang paling dominan jika dibandingkan dengan sumber-sumber daya yang lain dalam suatu perpustakaan. Apabila keinginan dan kebutuhannya dapat terpenuhi secara wajar, mereka akan memberikan kontribusi tertentu demi keberhasilan tujuan perpustakaan.

Di antara SDM, akan saling bahu-membahu dan berhubungan dalam menyelesaikan pekerjaan untuk mencapai tujuan perpustakaan yang telah ditetapkan. Beberapa hubungan kerja sama yang menyenangkan akan menimbulkan perasaan yang menyenangkan di antara anggota dalam tim kerja. Sebaliknya, pengalaman kerja sama yang tidak menyenangkan akan menimbulkan perasaan yang tidak menyenangkan pula.

Mengadopsi pemikiran Kohn \& O'Connell (2009: 212), beberapa contoh perasaan yang menyenangkan, misalnya: ada kasih sayang, perhatian, kegembiraan, suka cita, dan potensi berperilaku asertif. Sementara itu, kalau perasaan yang tidak menyenangkan seperti: depresi, takut, khawatir, merasa direndahkan, dicaci maki, dikritik, ketidakmampuan, sampai pada kemarahan dan kebencian.

Konsep kerja sama di antara SDM perpustakaan menunjukkan besarnya peran pengetahuan dari individu yang terlibat. Praktik kerja sama dibangun berdasarkan unsur-unsur budaya, yaitu nilai, norma, dan kepercayaan. Salah satu kunci layanan perpustakaan yang unggul dan prima adalah terbangunnya kerja sama tim yang solid di antara SDM yang ada di dalam perpustakaan tersebut.

Agar SDM yang bekerja di suatu perpustakaan dapat melaksanakan tugas dengan baik dalam rangka untuk mewujudkan layanan unggul dan prima, maka selain kerja sama di antara SDM perpustakaan, juga dipengaruhi oleh faktor lainnya. Faktor tersebut, misalnya: adanya apresiasi, lingkungan tempat kerja, peralatan, fasilitas pendukung kerja, gaji, insentif, perhatian pimpinan, keamanan, jaminan kesehatan dari instansi, dan berbagai macam faktor lainnya. Hal ini karena sumber daya manusia yang berkualitas pun tidak akan mampu berbuat optimal jika tidak didukung oleh sumber daya lainnya.

Saya rasa tidak akan ada yang acuh terhadap pekerjaan dan saling lempar tanggung jawab jika mereka mampu bekerja sama. Namun, yang namanya resistensi pasti ada dan tidak bisa dihindari. Menolak kerja sama dan tidak kooperatif menjadi indikatornya. Inilah salah satu hal yang saya sebut dengan konflik.

Resistensi yang dimaksud adalah bentuk penolakan secara individual dan menjadi suatu kebiasaan. Misalnya, pustakawan S selalu mengeluh di belakang punggung pimpinan kepada pustakawan lainnya yang kebetulan memiliki pandangan yang sama. Bisa dibayangkan pasti pustakawan $\mathrm{S}$ tersebut suka 'membicarakan' pimpinan di belakang dan menjadi tukang rumpi.

Bahkan, pustakawan yang menunda-nunda pekerjaan ataupun melakukan pekerjaan dengan perasaan terpaksa dan setengah hati tergolong resistensi juga. Sering telat masuk kantor, pulang lebih cepat dari waktu yang ditentukan, suka menggosip, maupun sering mengeluh juga menjadi ciri adanya resistensi pada diri SDM. 
Namun demikian, sebenarnya apabila masing-masing anggota dalam tim kerja dapat saling menjunjung tinggi dan memahami arti kebersamaan, maka akan tercipta sinergi di antara mereka. Kerja sama di antara SDM yang ada di perpustakaan diharapkan akan dapat tercapainya sebuah layanan perpustakaan yang prima dan unggul.

SDM yang dimaksud terkait dengan unsur manajemen dan staf, baik itu pustakawan, petugas perpustakaan, teknisi komputer, petugas kebersihan perpustakaan, tata usaha, satpam, dan SDM lainnya yang ada di perpustakaan. Dalam hal ini, intinya kerja sama dengan siapa pun yang ikut terlibat di dalam pengelolaan perpustakaan tersebut. Hubungan antaranggota tim menjadi penentu yang signifikan dalam proses kerja sama.

Setiap sumber daya manusia yang ada di sebuah perpustakaan dituntut untuk bekerja sama. Masing-masing individu tersebut merupakan bagian dari suatu kelompok. Hal ini selaras dengan salah satu aspek pada poin ketiga yang disampaikan oleh Sutarno (2006: 31) bahwa sumber daya manusia perlu diperhatikan dalam hal: (1) bagaimana membentuk dan mempersiapkan tenaga yang dapat berpikir rasional, memiliki kemampuan yang tangguh, sembada, mumpuni, profesional, proporsional, memiliki ketrampilan, mampu bersikap, (2) semangat bekerja, disiplin, tahu menghargai waktu, menjaga kepercayaan, kredibilitas, tepat janji, selalu jujur, (3) dapat bekerja sama (team work), komunikatif, berkoordinasi, ramah tamah, efisien, dan ekonomis.

Tidak mungkin satu orang bekerja sendiri. Pasti akan saling berhubungan dan membutuhkan keberadaan orang lain. Dari mengolah buku sampai buku siap dilayankan pasti juga berkaitan dengan orang lain. Jika SDM kompak dalam tim kerja, maka muaranya urusan layanan pemustaka menjadi unggul dan prima. Jadi, mau tidak mau harus bekerja sama dalam sebuah tim kerja.
Ada beberapa alasan yang disampaikan oleh Sopiah (2008: 26) tentang alasan kenapa seseorang bersedia menjadi bagian dari suatu kelompok. Alasan tersebut jika dibumikan dalam konteks perpustakaan, bisa dijelaskan sebagai berikut:

a. Rasa aman

Perasaan aman tersebut diperlukan bagi seorang pustakawan karena berada bersama teman-teman lainnya dalam suatu kelompok akan memberikan semangat dan motivasi. Misalnya, berada dalam satu instansi UPT Perpustakaan X dan bisa diterima sebagai bagian dari anggota kelompok yang bersangkutan, maka akan membuat perasaan pustakawan tersebut menjadi aman.

b. Status dan harga diri

Seorang pustakawan yang bergabung dalam suatu kelompok bisa bertujuan untuk meningkatkan status dan harga diri. Misalnya, bergabung dalam keanggotaan organisasi kepustakawanan, seperti IPI (baca I Pe I), kemudian bergabung menjadi pengurus ataupun sebagai anggota aktif forum kepustakawanan, seperti: FPPTI, FKP2TN, ISIPII, ATPUSI, KPI, dan sebagainya.

c. Interaksi dan afiliasi

Sebagai makhluk sosial, pustakawan juga membutuhkan orang lain untuk dapat berbagi pengetahuan, perasaan, pikiran, atau yang lain, sehingga untuk dapat berinteraksi dan berafiliasi, maka perlu bergabung dalam kelompok tertentu. Misalnya, pustakawan yang muslim bergabung dalam suatu majlis taklim di pengajian masjid kampus.

d. Kekuatan

Dalam kebersamaan, setiap pustakawan akan saling membantu dan memotivasi satu sama lain dan mempertahankan kebersamaan mereka. Dengan diterimanya 
dalam kelompok, maka pustakawan akan merasa memiliki kekuatan untuk mencapai tujuan bersama. Misalnya, pustakawan A yang menjadi bagian dari anggota Tim Penilai JFP, maka pustakawan A tersebut akan memiliki motivasi tersendiri untuk menilai angka kredit secara profesional dalam sebuah tim penilai.

e. Pencapaian tujuan

Pustakawan bergabung dalam kelompok didasarkan pada suatu harapan bahwa dengan berkelompok, maka diri pustakawan akan memiliki tenaga, bantuan, dan kekuatan yang lebih besar sehingga dapat mencapai tujuan dengan lebih mudah. Misalnya, pustakawan dilibatkan dalam rapat untuk memutuskan suatu hal, maka akan menjadi kekuatan tersendiri bagi pustakawan tersebut untuk ikut berperan serta dalam mewujudkan visi dan misi perpustakaan.

f. Kekuasaan

Pustakawan perlu menyalurkan kemampuannya untuk melakukan wewenang atas orang lain atau untuk mempengaruhi orang lain dalam mencapai tujuan perpustakaan yang diinginkan. Artinya, bahwa kemampuan tersebut merupakan kekuasaan yang hanya akan dapat berjalan jika pustakawan berada bersama orang lain.

\section{Proses Kerja Sama}

Proses kerja sama melibatkan seluruh SDM yang ada di perpustakaan. Praktik kerja sama menjadi suatu proses budaya yang dikonstruksi oleh interaksi antara SDM di perpustakaan yang tergabung dalam sebuah proses. Proses membangun praktik kerja sama umumnya melewati 5 (lima) tahap, yaitu:

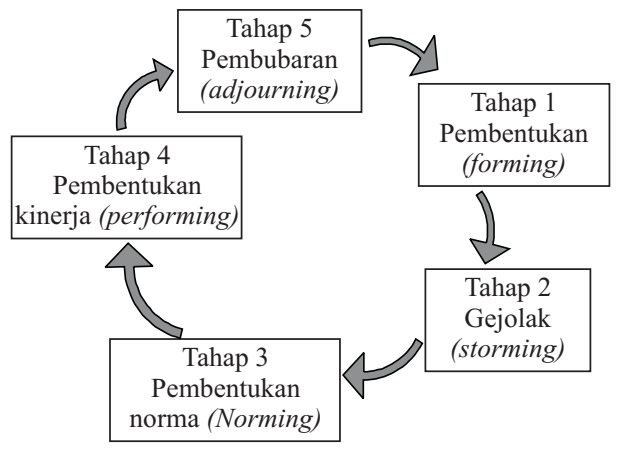

Gambar 1 Proses Membangun Praktik Kerja Sama

(Sumber: Dimodifikasi dari Laksmi, 2015: 31)

Pada gambar tersebut nampak tahapan proses kerja sama yang diawali dengan tahap pembentukan dan diakhiri dengan tahap pembubaran. Tahap pembentukan merupakan masa perkenalan anggota tim atau orientasi. Saling mengenal dan memahami SDM perpustakaan, mulai dari anggota tim yang tergabung dalam subseksi, seksi, subbidang, bidang, subbagian, bagian, atau SDM secara menyeluruh dalam lingkup SDM perpustakaan.

Tahap gejolak berarti muncul konflikkonflik yang berkaitan dengan kepentingan masing-masing. Perbedaan kepentingan inilah yang terkadang menimbulkan konflik. Mulai adanya konflik internal yang terjadi antarSDM, baik yang menyangkut urusan personal maupun organisasi. Munculnya kepentingan pribadi, seperti kepentingan untuk dihargai biasanya sering terjadi. Adanya konflik nyaris tidak bisa dihindari dalam setiap aktivitas, yang terpenting adalah berusaha mengelolanya agar ada solusi pemecahannya. Contoh: dalam suatu tim pengadaan jurnal, jurusan A mengatakan jurnal E lebih penting, kemudian program studi lainnya mengusulkan pengadaan jurnal $\mathrm{F}$ lebih penting, kemudian jurusan atau program studi lainnya beda lagi. Artinya, masing-masing mempunyai kepentingan dan alasan tersendiri mengapa perlu mengadakan jurnal tersebut di perpustakaan. 
Tahap pembentukan norma merupakan tahap yang lebih tenang karena anggota kerja sama sudah saling mengenal dan menerima satu sama lain. Dalam tahapan ini, ibaratnya sudah ada klik (clique) antar-SDM yang ada, mereka sudah bisa memahami masing-masing pihak, bisa menerima perbedaan, dan mempunyai tujuan yang sama dalam mewujudkan layanan perpustakaan yang prima dan unggul. Dalam praktik kerja sama, para anggota saling menyepakati adanya nilai, norma, simbol, keyakinan tertentu yang mengatur keberlangsungan kerja sama.

Tahap pembentukan kinerja merupakan periode anggota kerja sama untuk bekerja mencapai tujuan. Antar-SDM perpustakaan saling bersinergi dan bekerja sama dalam menyelesaikan pekerjaan. Tidak ada yang namanya iri terhadap jenis pekerjaan, tapi masing-masing individu sudah menyadari apa yang menjadi tugas dan tanggung jawab, serta kewajibannya.

Selanjutnya, yang terakhir, yaitu tahap pembubaran, berarti jika tujuan kerja sama telah tercapai, maka tim dapat dibubarkan. Artinya, bukan berarti terus bubar selesai, namun hal ini menunjukkan adanya sebuah akhir dari siklus. Kerja sama antar-SDM perpustakaan tetap harus dilakukan dan ditegakkan. Terkecuali jika tim kerja dalam sebuah kepanitiaan, seperti panitia seminar perpustakaan, maka perlu adanya pembubaran panitia.

\section{Relasi Sosial}

Relasi sosial antar-SDM di perpustakaan akan mendorong munculnya peran dari masing-masing individu. Peran setiap SDM di perpustakaan berbeda-beda sesuai dengan tugas yang diembannya. Laksmi (2015: 36) menjelaskan bahwa praktik kerja sama yang efektif dan efisien di tempat kerja sangat membutuhkan hubungan atau relasi sosial di antara individu yang terlibat.
Relasi sosial merupakan hubungan antarindividu dalam suatu sistem sosial. Dalam kehidupan sehari-hari, tidak satu pun individu yang dapat melakukan tindakan tanpa memiliki pengaruh pada orang lain. Sedangkan praktik kerja sama berdasarkan berbagai pengetahuan adalah hubungan kerja sama antarindividu, unit, atau lembaga yang secara informal menentukan alur komunikasi di antara pekerja.

Kerja sama berdasarkan relasi sosial memungkinkan terciptanya hubunganhubungan antar-SDM perpustakaan berdasarkan kepentingan tertentu sehingga terbentuk klik. Hubungan atau relasi sosial terbentuk oleh adanya rasa saling percaya, saling menghargai dan menghormati, dapat menerima perbedaan pendapat, dan nilai-nilai positif lainnya. Hubungan inilah yang disebut sebagai modal sosial (capital social).

Pengertian modal sosial menurut Bourdieu (2010) sebagaimana yang juga dikutip oleh Laksmi (2015: 36) adalah:

"sumber daya yang dimiliki oleh seseorang yang berasal dari jaringan sosial yang terlembagakan yang berlangsung terus-menerus dalam bentuk pengakuan dan perkenalan timbal baik (keanggotaan dalam kelompok sosial) yang memberikan anggotanya berbagai bentuk dukungan kolektif".

Masing-masing SDM di perpustakaan bekerja sama karena didorong oleh adanya relasi kekuasaan. Maksudnya, bahwa hubungan yang dimiliki oleh setiap individu tersebut yang oleh karena posisinya akan memungkinkan untuk melaksanakan keinginannya meskipun sebenarnya ada perlawanan.

Namun demikian, relasi kekuasan di dalam kerja sama disebabkan juga oleh lemahnya modal sosial. Kekuasaan yang dimaksud lebih menunjukkan pada suatu hubungan sosial dan relasi sosial merujuk pada hubungan tukar- 
menukar yang salah satunya timpang atau tidak memiliki nilai yang sama (nilai yang satu lebih besar dari yang lain).

Kemudian jika dicermati, sebenarnya istilah dari kerja sama sudah dikenalkan sejak zaman nenek moyang kita dalam bentuk gotong royong. Namun, sepertinya saat ini nilai gotong royong menjadi luntur dan ada pergeseran, baik dari sisi istilah, makna, dan fungsi. Hal ini seperti apa yang disampaikan Abdullah (2006: 149) bahwa gotong royong, terutama di masyarakat Jawa yang di masa lalu memiliki peran penting dalam memecahkan berbagai masalah komunitas dan menunjukkan kuatnya nilai kebersamaan dan solidaritas, kini mengalami pergeseran makna dan fungsi.

\section{Pertukaran Pengetahuan}

Pengetahuan yang dimiliki oleh setiap SDM perpustakaan merupakan modal kultural. Selanjutnya, individu yang memiliki modal kultural tersebut biasanya menunjukkan kekuasaan dan status sosial. Hal ini seperti apa yang dikemukakan oleh Bourdieu (2010) bahwa modal kultural adalah penguasaan informasi dalam segala bentuk, yang salah satunya adalah pengetahuan.

Dalam pertukaran pengetahuan ini, Laksmi (2015: 39) memberikan konsep Evidence Best Practices (EBP) dan Communities of Practices (CoP). Berbagi pengalaman bisa berupa diskusi dan bertukar pengalaman dalam bentuk praktikpraktik terbaik (best practices) dan jika di luar lembaga, biasanya mereka membentuk apa yang disebut sebagai Communities of Practices (CoP).

Konsep kerja sama di tempat kerja, terutama di lembaga informasi, menekankan hubungan antara ilmuwan, profesional informasi, dan masyarakat, yang didukung oleh evidence. Konsep EBP tersebut merupakan metode yang memanfaatkan hasil penelitian dan pengalaman di antara ilmuwan, praktisi di pusat informasi, dan penyebaran informasi tersebut kepada masyarakat. Pendekatan ini digunakan secara umum untuk praktisi, termasuk para pustakawan dan pengelola perpustakaan yang berurusan dengan segala hal tentang informasi.

Dalam CoP, para anggota saling belajar satu sama lain untuk menjadi lebih baik. Kerja sama dalam CoP dibangun oleh 3 (tiga) elemen dasar, yaitu pengetahuan tertentu, komunitas atau sekumpulan orang pemerhati bidang pengetahuan dan adanya kegiatan berbagi pengetahuan. Konsep CoP menurut Wenger, et. al. (2002) yang dikutip oleh Laksmi (2015: 43), artinya sekelompok orang yang saling berinteraksi untuk berbagi pengetahuan dalam minat dan hobi tertentu.

Penerapan CoP untuk SDM di perpustakaan berarti sekelompok orang yang menjadi SDM di perpustakaan saling berinteraksi dalam berbagai minat dan hobinya, kemudian mereka saling belajar satu sama lain untuk menjadi lebih baik dalam minat dan hobinya tersebut. Misalnya, pustakawan yang sama-sama mempunyai minat membuat software, maka mereka akan membuat kelompok atau komunitas sesama programmer untuk bisa saling belajar dan berbagi pengalaman.

Kerja sama akan efektif jika didukung oleh pertukaran pengetahuan antara anggota tim. Caranya dengan berbagi pengalaman, pengetahuan, dan ketrampilan yang dimiliki. SDM yang tidak bisa membuat indeks artikel jurnal bisa belajar dengan SDM lain yang memang ahli dalam mengindeks, kemudian yang tidak bisa menentukan tajuk subjek bisa minta diajari dengan yang memang sudah pakar menentukan tajuk subjek, dan berbagai jenis pekerjaan lainnya di perpustakaan.

Oleh karena pertukaran pengetahuan merupakan proses transfer pengetahuan yang dilakukan secara learning by doing, maka SDM yang memiliki jenis pekerjaan yang sama dapat berbagi pengetahuan tentang metode terbaik dalam menyelesaikan pekerjaan. Suatu contoh 
dalam penggunaan software tertentu untuk penelusuran informasi.

Mereka bisa belajar dan mendiskusikan bersama dalam membahas permasalahan yang ada pada setiap bagian di perpustakaan sehingga diharapkan dapat menemukan solusi yang tepat. Misalnya, tim kerja di bagian layanan pemustaka, bisa saling belajar bagaimana cara melayani yang cepat dan tepat, baik terkait dengan layanan referensi, layanan sirkulasi, layanan karya ilmiah, layanan terbitan berkala, maupun layanan lainnya.

\section{PENUTUP}

Konstruksi sosial dengan membangun kerja sama di antara SDM di perpustakaan merupakan suatu proses kultural. Praktik kerja sama antarSDM di perpustakaan dapat diamati dari dua aspek, yaitu berdasarkan aspek relasi sosial dan pertukaran pengetahuan. Kerja sama di antara SDM di perpustakaan menjadi kunci menuju layanan perpustakaan unggul dan prima.

\section{DAFTAR PUSTAKA}

Abdullah, I.. 2006. Konstruksi dan Reproduksi Kebudayaan. Yogyakarta: Pustaka Pelajar.

Bourdieu, P.. 2010. Arena Produksi Kultural: Sebuah Kajian Sosiologi Budaya. Bantul: Kreasi Wacana.

Kohn, S.E. \& O’Connell, V.D.. 2009. 6 Kebiasaan Tim yang Sangat Efektif (Terjemahan). Tangerang: Binarupa Aksara.

Laksmi. 2015. Konsep dan Praktik Kerja Sama Antar Individu di Lembaga Informasi. Edisi ke-2. Jakarta: ISIPII.

Lasa, H.S.. 2005. Manajemen Perpustakaan. Yogyakarta: Gama Media.Sopiah. 2008. Perilaku Organisasional. Yogyakarta: Andi.

Sutarno, N.S.. 2006. Manajemen Perpustakaan: Suatu Pendekatan Praktik. Jakarta: Sagung Seto. 